\section{Ювілеі}

Annivesary
ISSN: 2411-6181(on-line); ISSN: 2311-9896 (print)

Current issues of social studies and history of medicine. Joint Ukrainian -Romanian scientific journal, 2019, №:4(24), P. 40-43 UDK 616-073.75(091)

DOI 10.24061/2411-6181.4.2019.148

\author{
ПРОФЕСОР ГІГІЕНИ І САНОЛОГІЇ ЛЬВІВСЬКОГО \\ УНІВЕРСИТЕТУ ЮЗЕФ МЕРУНОВИЧ - БАГАТОРІЧНИЙ \\ ГОЛОВА ТОВАРИСТВА ГАЛИЦЬКИХ ЛІКАРІВ \\ ВолодИМИр ГРИНОВЕЦЬ ${ }^{1}$, ОльГа ПЕТРИШИН ${ }^{1}$, \\ Наталія СКАЛЕЦЬКА ${ }^{1}$, Юрій ШАШКОВ ${ }^{2}$, \\ Оксана ПАСЬКО ${ }^{1}$, Оксана ІЛЬЧИШИН ${ }^{1}$, \\ Марта ДАЦ-ОПОКА ${ }^{1}$, Ігор ГРИНОВЕЦЬ \\ ${ }^{1}$ Львівський національний медичний \\ університет імені Данила Галицького, м. Львів (Україна) \\ ${ }^{2}$ Вищий навчальний комунальний заклад Львівської обласної ради \\ “Львівська медична академія імені Андрея Крупинського”, м. Львів (Україна) \\ hrynovets@ukr.net; olga_petryshyn@yahoo.com; sknm@i.ua; \\ shashkow@ukr.net; lvgeorg@ukr.net; immartella@gmail.com; martadats@gmail.com
}

\title{
PROFESSOR OF HYGIENE AND SANOLOGY AT THE \\ UNIVERSITY OF LVIV JOZEF MERUNOVYCH AS A \\ LONGTIME CHAIRMAN OF THE SOCIETY OF GALICIAN DOCTORS \\ Volodymyr HRYNOVETS ${ }^{1}$, Olga PETRYSHYN ${ }^{1}$, \\ Nataliya SKALETSKA ${ }^{1}$, Yurii SHASHKOV ${ }^{2}$,
}

Oksana PASKO ${ }^{1}$, Oksana ILCHYSHYN ${ }^{1}$,

Marta DATS-OPOKA ${ }^{1}$, Igor HRYNOVETS ${ }^{1}$

${ }^{1}$ Danylo Halytsky Lviv National Medical Univesity, Lviv (Ukraine),

${ }^{2}$ Lviv Medical Academy by A. Krupinskiy, Lviv (Ukraine)

ORCID 0000-0002-6359-3793; RESEARCHER ID U-2999-2018

ORCID 0000-0003-0203-6341; RESEARCHER ID U-3009-2018

ORCID 0000-0003-2382-6262; RESEARCHER ID G-2040-2019

ORCID 0000-0002-8205-9959;

ORCID 0000-0001-9223-1479; RESEARCHER ID U-3007-2018

ORCID 0000-0003-2854-9743 ; RESEARCHER ID G-4633-2019

ORCID 0000-0002-2797-2462

ORCID 0000-0003-1727-3526

Гриновець Владимир, Петрушин Ольга, Скалецкая Наталья, Шашков Юрий, Пасько Оксана, Ильчишин Оксана, Дац-Опока Марта, Гриновець Игорь. Профессор гигиены и санологии Львовского университета Юзеф Мерунович - многолетний председатель Общества галицких врачей. Цель работы. Исследования и изучения исторического наследия развития организации медицинской помощи в Галичине, становления науки гигиены и общественных медицинских организаций XIX $\square \mathrm{XX}$ века на примере врача, протомедика Галичины, государственного и общественного деятеля $\square$ профессора Львовского университета Юзефа Меруновича. Материал и методы. В исследование увийшлидоступни материалы библиотек ЛНМУ имени Даниила Галицкого, ЛНУ имени Ивана Франко, энциклопедические, журнальные и газтни статьи. Результаты. В результате изучения биографических данных и исследования деятельности профессора Юзефа Меруновичабуло определено европейский уровень организации медицинской службы Галичины, который сочетался с научной сотрудничеством медицинского факультета Львовского университета. Выводы. Оценивая жизненный путь профессора Юзефа Меруновича, и анализируя его вклад в развитие и становления медицинской науки, его организаторские способности как государственного служащего, общественного деятеля медицинского профиля, можно смело утверждать о надлежащем европейском уровне организации медицинской службы в Галичине в указанный период.

Ключевые слова: протомедик Галичины, профессор Львовского университета, Юзеф Мерунович

У 2019 році відзначається 170 років від дня народження відомого професора медицини Львівського університету Юзефа Меруновича - лікаря, науковця, організатора гігієнічної служби Галичини, державного та громадського діяча. Досліджуючи становлення громадських організацій Галичини XIX сторіччя, зокрема Товариства галицьких лікарів у процесі розвитку медицини, гігієни та санітарії, неможливо оминути внесок професора гігієни і соматології доктора Юзефа Меруновича (рис. 1).
3 архівних матеріали довідуємося, що Юзеф Мерунович (Józef Merunowicz) народився 31 грудня 1849 р. у Чернівцях на Буковині, навчався у Дрогобицькій та Львівській гімназіях, а опісля на медичному факультеті Ягелонського університету, який завершив у 1873 р. та отримав ступінь доктора наук у всіх медичних науках. В 1873-75 рр. працював асистентом клініки цього ж університету ${ }^{1}$.

Після отримання імперської стипендії працював впродовж трьох семестрів у фізіологічному інституті в

\footnotetext{
${ }^{1}$ Wiczkowski J. Lwów jego rozwój i stan kulturalny oraz przewodnik po meście Lwów [Lviv, its development and cultural status, and a guide to the Lviv city], 1907, 341-344 [in Polish]; Kosmiński S. Słownik lekarzów polskich [Dictionary of Polish Doctors], Warszawa, 1888, 313-314 [in Polish]; Zimenkovskyi B. S., Gzhehotskyi M. R., Lutsyk O. D. Profesory Lvivskoho natsionalnoho medychnoho univeuniversytetu imeni Danyla Halytskoho: 1784-2006 Pavlovskyi M. P., Riznychok S. V., Merunovych Yuzef [Professors of Danylo HalytHalytsky National Medical University of Lviv: 1784-2006 Pavlovskyi M .P., Riznychok S.V., Jozef Merunovych], Lviv, Nautilus, 2006, 187-188 [in Ukrainian].
} 


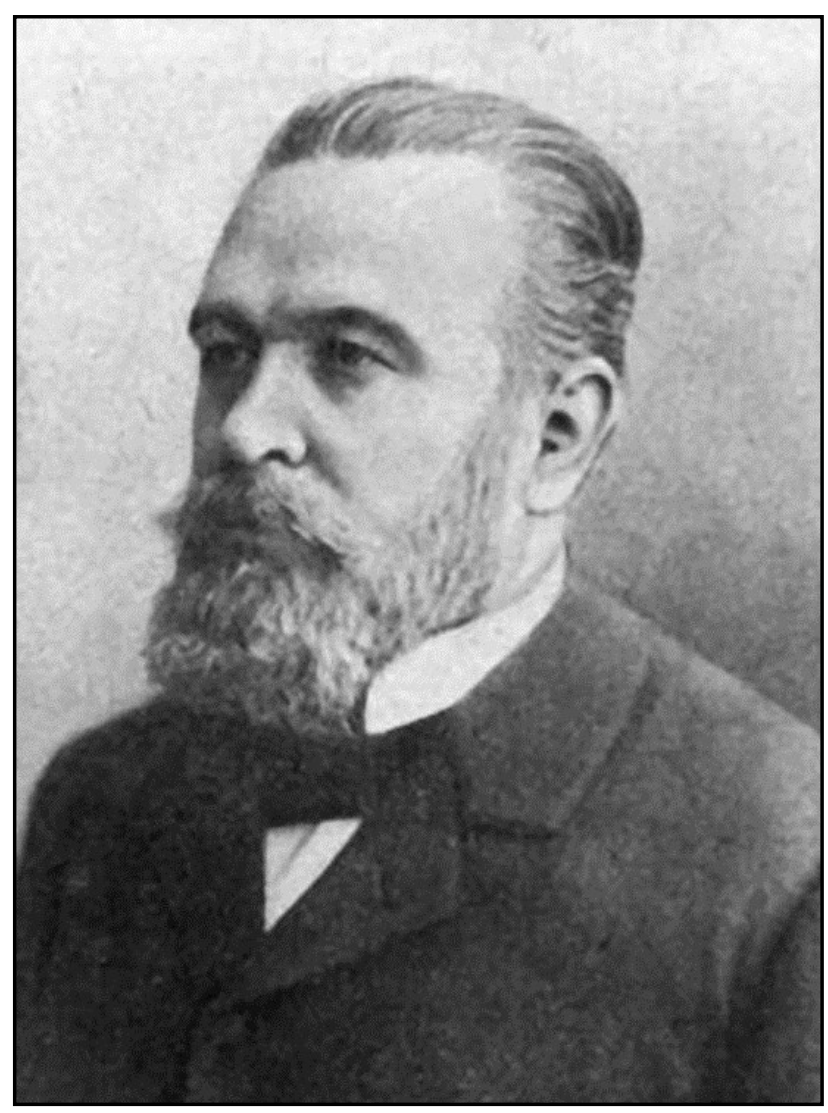

Рис. 1. Юзеф Мерунович (Józef Merunowicz)

Лейпцигу під керівництвом професора Людвіга.

Після стажування впродовж 1875 р. в клініках Лейпціга, Відня, Вроцлава розпочав приватну практику в місті Станіславові в Галичині (1876-1878 рр.).
Через два роки він переїхав у Львів. У 1878 р., відповідно до розпорядження цісарсько-королівської канцелярії, доктора Меруновича Юзефа було призначено протомедиком Галичини ${ }^{2}$.

Упродовж 1878-1912 рр. перебування Ю. Меруновича на посаді протомедика Галичини він був керівником Департаменту санітарії у Львові, виконував обов'язки референта (інспектора) у справах санітарії галицького краю, безпосередньо був зайнятий у забезпеченні та інспекції гігієнічно-санітарних норм краю до 1912 р. За час перебування на цій посаді доктор Мерунович активно займався науковою роботою та громадською діяльністю.

Впродовж 1887-1889 рр. доктор Мерунович, за сумісництвом професор гігієни і соматології Львівського університету, викладає студентам медикам гігієну, видає близько 20 праць присвячених таким питанням, як фізіологія та патологія діяльності серця та фармакологічна корекція цих порушень, клініка отруєнь арсеном, гігієнічні дослідження причин смертності в містах Галичини, опублікував низку актуальних на той час досліджень, зокрема "Смертність у більших містах Галичини"

Професор Юзеф Мерунович проявив себе як організатор і багаторічний директор Імператорської школи акушерок у Львові (1889-1912 рр.), яку завдяки старанням професора у 1895 р. було перенесено у нове приміщення клініки шпиталю на вул. Піярів (тепер вул. Некрасова) (рис.2). Долучився й до розвитку здравниці у Криниці ${ }^{4}$.

Активно займався професор Мерунович громадською діяльністю. У 1885-1886 рр. - голова Львівської секції Товариства галицьких лікарів (ТГЛ); у 18951910 pp. - голова ТГЛ, пізніше був почесним членом

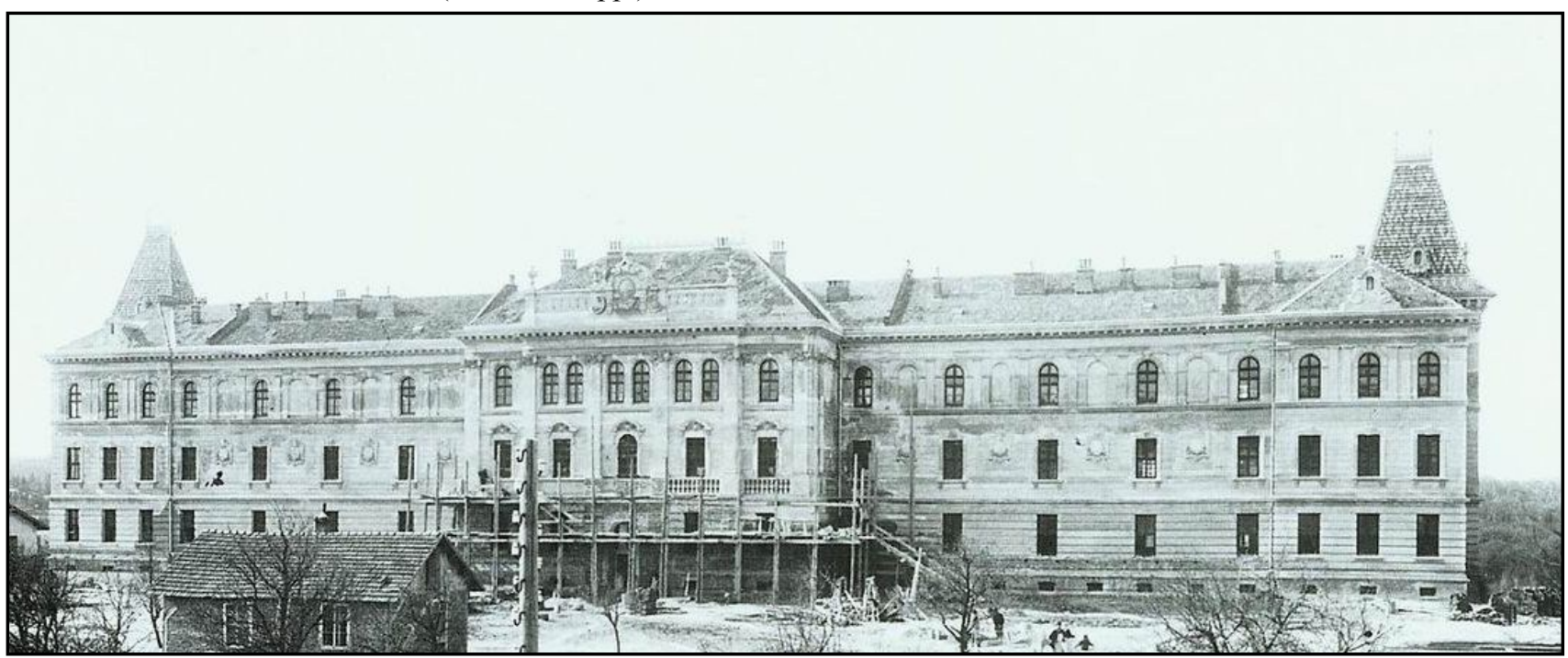

Рис.2. Новозбудований корпус клініки шпиталю на вул. Піярів (1895) (тепер вул. Некрасова у Львові)

\footnotetext{
${ }^{2}$ Kosmiński S. Słownik lekarzów polskich [Dictionary of Polish Doctors], Warszawa, 1888, 313-314 [in Polish]; Starzyński S. Historya Uniwersytetu Lwowskiego 1869-1894 [Historian of the University of Lviv 1869-1894], Lwów, 1894, T. 2: 132, 180 [in Polish].

${ }^{3}$ Назву цитовано за польським виданням (Śmiertelność w większychmiastach w Galicyi w r. 1881. Przegl. Lek. 1882, № 18, 20); Zimenkovskyi B. S., Gzhehotskyi M. R., Lutsyk O. D. Profesory Lvivskoho natsionalnoho medychnoho universytetu imeni Danyla Halytskoho: 1784-2006 Pavlovskyi M. P., Riznychok S. V., Merunovych Yuzef [Professors of Danylo Halytsky National Medical University of Lviv: 1784-2006 Pavlovskyi M. P., Riznychok S. V., Jozef Merunovych], Lviv, Nautilus, 2006, P. 187-188 [in Ukrainian].

${ }^{4}$ Wiczkowski J. Lwów jego rozwój i stan kulturalny oraz przewodnik po meście Lwów [Lviv, its development and cultural status, and a guide to the Lviv city], 1907, P. 341-344 [in Polish].
} 
Лейпцигу під керівництвом професора Краківського та Львівського медичних товариств. Будинок в якому знаходилася управа товариства станом на 1907 рік зберігся на вул. Івана Федорова, 1 (приміщення 11). На той час це булла вул. Бляхарська (ul.Blacharska), до 1871 p. - вул. Домініканська бічна (рис. 3$)^{5}$.

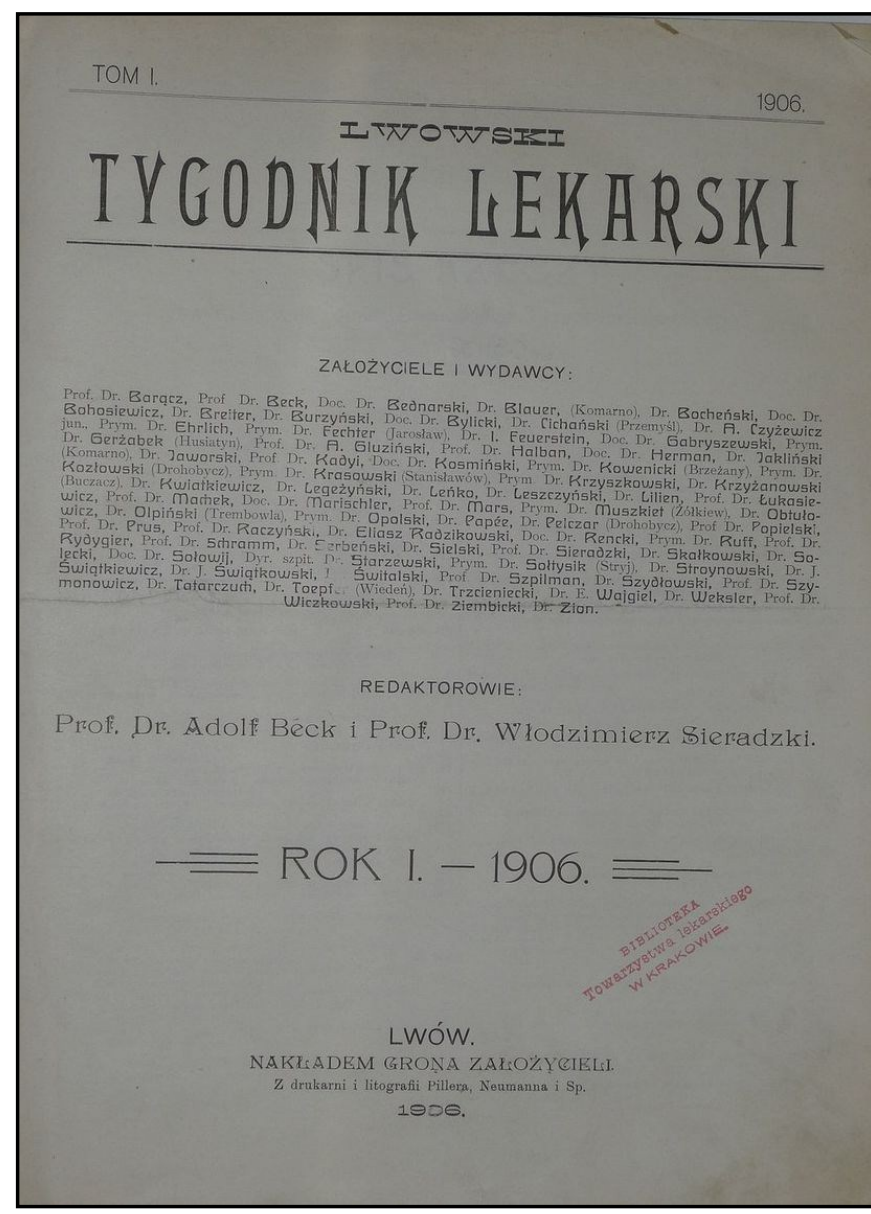

Рис. 3. Часопис "LWOWSKI TYGODNIK LEKARSKI” (Львівський Тижневик Лікарський)

Органом товариства був часопис "LWOWSKI TYGODNIK LEKARSKI” (Львівський Тижневик Лікарський), що виходив раз на тиждень (рис.3).

1900-1911 pp. - голова Постійної комісії з'їздів польських лікарів і природознавців (займався організацією Х-го та ХІ-го з'їздів). новича.

У 1898 р. була створена фундація імені Ю. Меру-

Професор Ю. Мерунович був відзначений орденом Залізної Корони III класу (1893 р.), мав титул радника двору (1901р.), у 1910 році отримав високий Ранг радника двору (1910р.). Обирався головою Товариства

\section{Червоного Хреста у Львові ${ }^{6}$.}

Професор Юзеф Мерунович після піврічної хвороби помер 9 квітня 1912 р., похований на Личаківському цвинтарі у Львові) (рис. 4) 7 . 3 опублікованого некролога у “Львівському кур'єрі” (Kurier Lwowski) дізнаємося, що професор заповів не нести вінків на його могилу та не виголошувати довгих промов, а кошти, які мали б бути витрачені - надіслати до фонду допомоги сиротам та вдовам лікарів. Незадовго до смерті професора померла його дружина Антоніна Меруновичова зі Страссерів, неймовірно гарна жінка та вірна товаришка у трудах свого чоловіка. У подружжі прожили разом 38 років та виховали шестеро дітей: чотирьох синів та двох доньок. Двоє синів, Роман та Іоанн продовжили справу батька на теренах медицини, зокрема Роман - дільничним лікарем в м. Хжа́нув (Chrzanów); Фелікс - директор банку муніципальних заощаджень в Самборі, Зигмунт - технічний співробітник фінансового контролю т

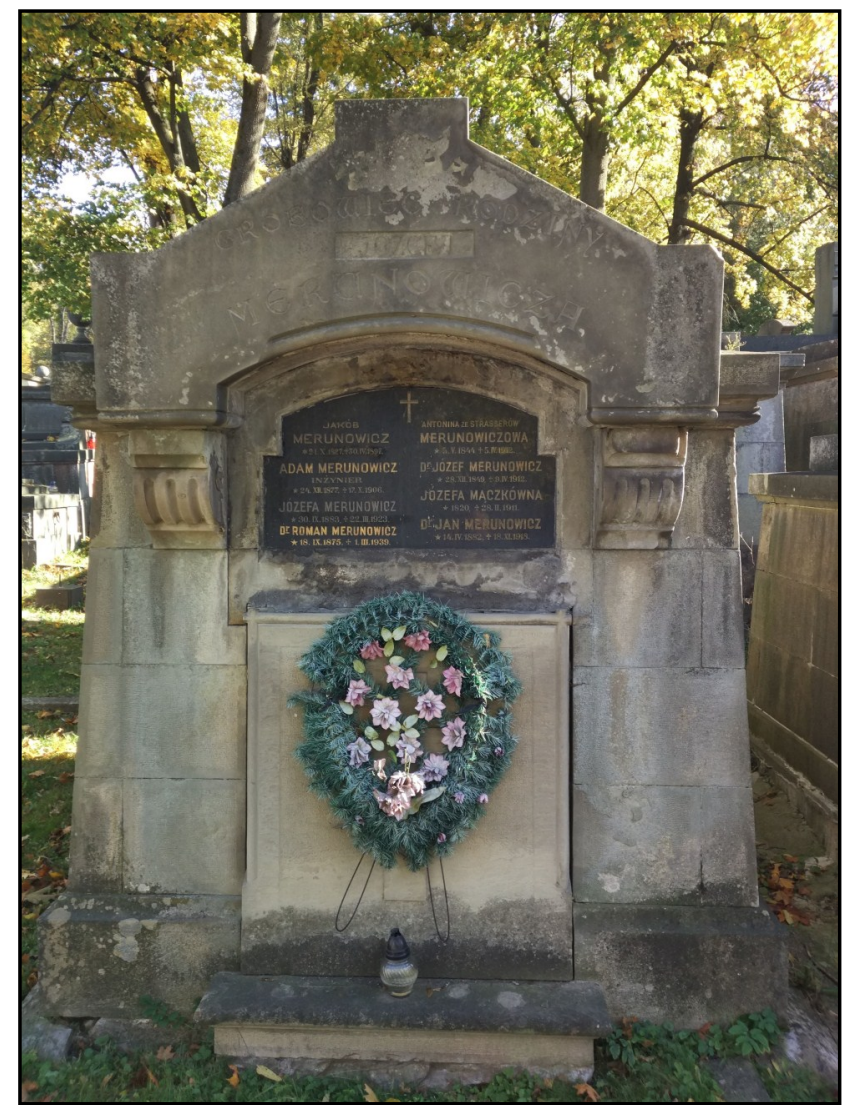

Рис. 4. Гробівець у якому похований Ю. Мерунович

а долучився до створення університету для вивчення продуктів в Кракові ${ }^{8}$.

Відзначаючи доробок та внесок професора Юзефа

\footnotetext{
${ }^{5}$ Herman M. W. Z kroniki Towarzystwa Lekarskiego Lwowskiego [From the chronicle of the Lviv Medical Society], Lwów, 1907, P. 18 [in Polish]; Czasop Galic Tow Aptek [Galic Tow Pharmacies], 1912, N 5, P. 65-66 [in Polish]; Hrynovets V. S., Petryshyn O. A. "Profesor Yuzef Merunovych - holova tovarystva Halytskykh likariv" [Professor Józef Merunovich is the head of the Society of Halych Doctors], Narodne zdorovia [Public health], 2018, N 3(348), P. 6 [in Ukrainian].

${ }^{6}$ Wiczkowski J. Lwów jego rozwój i stan kulturalny oraz przewodnik po meście Lwów [Lviv, its development and cultural status, and a guide to the Lviv city], 1907, 341-344 [in Polish]; Zimenkovskyi B. S., Gzhehotskyi M. R., Lutsyk O. D. Profesory Lvivskoho natsionalnoho medychnoho universytetu imeni Danyla Halytskoho: 1784-2006 Pavlovskyi M.P., Riznychok S. V., Merunovych Yuzef [Professors of Danylo Halytsky National Medical University of Lviv: 1784-2006 Pavlovskyi M.P., Riznychok S.V., Jozef Merunovych], Lviv, Nautilus, 2006, P. 187-188 [in Ukrainian].

${ }^{7}$ Lupii H. Lychakivskyi tsvyntar [Lychakiv Cemetery], Lviv, Kameniar, 1996, P. 224 [in Ukrainian]; Pavlovskiy M. P., Datsenko I. I. Acta Med Leopol, 1995, N 2-3, P. 92 [in Ukrainian].

${ }^{8}$ Czasop Galic Tow Aptek [Galic Tow Pharmacies], 1912, N 5, 65-66 [in Polish]; Pavlovskiy M. P., Datsenko I. I. Acta Med Leopol, op. cit., P. 92.
} 
Меруновича необхідно відзначити, що він своєю працею як організатор доклався до становлення та модернізації клінічного та гігієнічного забезпечення населення Галичини. Будучи відданим обраній професії, професор Юзеф Мерунович усе своє життя присвятив саніта рно-просвітницькій роботі та зробив значний внесок у розвиток гігієнічної науки і санітарної практики Галичини, активно працюючи та керуючи Товариством галицьких лікарів, чим заслужив гідну пам'ять нащадків.

Hrynovets Volodymyr, Petryshyn Olga, Skaletska Nataliya, Shashkov Yurii, Pasko Oksana, Ilchyshyn Oksana, DatsOpoka Marta, Hrynovets Igor. Professor of hygiene and sanology at the university of Lviv Jozef Merunovych as a longtime chairman of the Society of Galician doctors. The aim. Research and study of the historical legacy of the development of medical aid organization in Galicia, the formation of hygiene science and public medical organizations of the nineteenth and twentieth centuries. on the example of the activity of a physician, protomedic of Galicia, state and public figure $\square$ professor of Lviv University Jozef Merunovich. Material and methods. The study included available materials from the Danilo Halytskyi LNMU, Ivan Franko LNU, encyclopedic, journal and newspaper articles. Results. As a result of studying biographical data and researching the activities of Professor Jozef Merunovich, the European level of organization of the medical service of Galicia was determined, which was combined with the scientific cooperation of the Faculty of Medicine of Lviv University. In addition, the high level of public activity of doctors and health care professionals is evidenced by the presence of well-organized public organizations of physicians of Galicia in the 19th-20th centuries. Conclusions. Assessing the life of Professor Jozef Merunovich and analyzing his contribution to the development of hygiene and sanology as a medical science, the establishment of health care facilities, organizational skills as a public servant, public figure in the medical profile, we can say that the proper European level of organization of medical service in Galicia of the twentieth century, which was certainly continued and these results are still observed today.

Key words: protomedic in Galicia, Lviv University, professor Jozef Merunovich, XIX-XX centuries.

Гриновець Володимир - к.мед.н., доцент кафедри терапевтичної стоматології, Львівський національний медичний університет імені Данила Галиџького, м. Львів, Украйна. У науковому доробку автора - більше 79 надрукованих праць. Коло наукових інтересів: терапевтична стоматологія, історія медицини.

Hrynovets Volodymyr - PH.D., Associate Professor, Department of Therapeutic Dentistry, Danylo Halytskyi Lviv National Medical University, Lviv, Ukraine. In the scientific heritage of the author - 79 published works. Scientific interests: therapeutic dentistry, history of medicine.

Петришин Ольга - к.мед.н., доцент кафедри терапевтичної стоматології, Львівський національний медичний університет імені Данила Галицького, м. Львів, Украйна. У науковому доробку автора - більше 62 надрукованих праць. Коло наукових інтересів: терапевтична стоматологія, історія медицини.

Petryshyn Olga - PH.D., Associate Professor, Department of Therapeutic Dentistry, Danylo Halytskyi Lviv National Medical University, Lviv, Ukraine. In the scientific heritage of the author62 published works. Scientific interests: therapeutic dentistry, history of medicine.

Скалецька Наталія - к.мед.н., асистент кафедри радіології та радіаційної медицини, Львівський національний медичний університет імені Данила Галицького, м. Львів, Україна. Коло наукових інтересів: радіологія, гігієна, екологія. Автор понад 64 наукових прачь.

Skaletska Nataliya - PH.D., Assistant Professor, Department of radiology and radiation medicine, Danylo Halytsky Lviv National Medical Univesity, Lviv, Ukraine. Scientific interests: radiology, hygiene, ecology. Author of more than 64 scientific papers.

Шашков Юрій - асистент кафедри лабораторної меди чини, ВНКЗ ЛОР «Львівська медична академія імені Андрея Крупинського», м. Львів, Україна. У науковому доробку автора - більше 34 надрукованих прачь. Коло наукових інтересів: історія медицини

Shashkov Yurii - Assistant Professor, Department of Laboratory Medicine Medical Academy by A. Krupinskiy, Lviv, Ukraine. In the scientific heritage of the author - 34 published works. Scientific interests: history of medicine.

Пасько Оксана - к.мед.н., дочент кафедри терапевтичної стоматології, Львівський національний медичний університет імені Данила Галищького, м. Львів, Украӥна. У науковому доробку автора - більше 59 надрукованих праџь. Коло наукових інтересів: стоматологія.

Oksana Pasko - PH.D., Associate Professor, Department of Therapeutic Dentistry, Danylo Halytsky Lviv National Medical Univesity, Lviv, Ukraine. In the scientific heritage of the author59 published works. Scientific interests: therapeutic dentistry.

Ільчишин Оксана - к.мед.н., дочент кафедри радіології та радіаційної медицини, Львівський національний медичний університет імені Данила Галищького, м. Львів, Украӥна. Коло наукових інтересів: рентгенологія, променева діагностика $i$ терапія. Автор понад 73 наукових прачь.

Ilchyshyn Oksana - PH.D., Associate Professor, Department of radiology and radiation medicine ,Danylo Halytsky Lviv National Medical Univesity, Lviv, Ukraine. Author of more than 73 scientific papers. Scientific interests: radiology, radiation diagnostics and therapy.

Дац-Опока Марта - к.мед.н., асистент кафедри пропедевтики педіатрії та медичної генетики, Львівський національний медичний університет імені Данила Галицького, м. Львів, Украӥна.

Dats-Opoka Marta - PH.D., Assistant Professor, Department of Propaedeutic Pediatrics and Medical Genetics, Danylo Halytsky Lviv National Medical Univesity, Lviv, Ukraine. Scientific interests: pediatrics, medical genetics. Author of more than 48 scientific papers.

Гриновець Ігор - к.мед.н., кафедра технології ліків $i$ біофармації, Львівський національний медичний університет імені Данила Галиџького, м. Львів, Украӥна. У науковому доробку автора - більше 62 надрукованих пращь. Коло наукових інтересів: біофармачія, технологія виготовлення ліків, історія медииини.

Hrynovets Igor - PH.D., Associate Professor, Department of radiology and radiation medicine, Danylo Halytsky Lviv National Medical Univesity, Lviv, Ukraine. In the scientific heritage of the author - 62 published works. Scientific interests: biopharmacy, drug manufacturing technology, history of medicine.

Received: 02.10 .2019

Advance Access Published: December, 2019

(C) V. Hrynovets, O. Petryshyn, N. Skaletska, Y. Shashkov, O. 